\title{
KRT20 wt Allele
}

National Cancer Institute

\section{Source}

National Cancer Institute. KRT20 wt Allele. NCI Thesaurus. Code C96458.

Human KRT 20 wild-type allele is located in the vicinity of 17 q21.2 and is approximately 9 $\mathrm{kb}$ in length. This allele, which encodes keratin, type I cytoskeletal 20 protein, is involved in the modulation of intestinal development. 